\title{
E-Marketing Produk NU Skin pada Rumah Cantik G\&G Berbasis Android
}

\author{
Gun Sudiryanto $^{1)}$, R. Hadapiningradja Kusumodestoni ${ }^{2)}$, Teguh Tamrin ${ }^{3)}$, Lusi \\ Meriyanti $^{4)}$ \\ Fakultas Sains dan Teknologi, Unisnu Jepara ${ }^{1)}$ Fakultas Sains dan Teknologi, Unisnu Jepara ${ }^{2)}$, Fakultas Sains \\ dan Teknologi, Unisnu Jepara ${ }^{3)}$ Fakultas Sains dan Teknologi, Unisnu Jepara ${ }^{4)}$ \\ gunsudiryanto@unisnu.ac.id ${ }^{1)}$, kusumodestoni@unisnu.ac.id $^{2)}$, teguh@unisnu.ac.id ${ }^{3)}$, \\ lusimeriyanti@gmail.com ${ }^{4}$
}

Katakunci: Abstrak:

Rumah Cantik, Aplikasi GEG, $\mathrm{Nu}$ Skin adalah salah satu produk kecantikan dan $R A D$, Kotlin, Android Studio kesehatan, salah satunya terletak di Jepara, yaitu G\&G Beauty House yang memiliki kantor di J1. Diponegoro No. 121, Jobokuto, Distrik Jepara. Pemasaran produk masih menggunakan cara tradisional dan sederhana yaitu melalui media Instragram dan Whatsapp, setiap kali produk dibeli, konsumen harus datang ke toko untuk mengetahui persediaan produk yang tersedia. Dilihat dari masalah tersebut, maka perlu adanya suatu aplikasi berbasis android yang dapat membantu kegiatan penjualan mulai dari mempromosikan produk, mengetahui informasi produk dan stok produk sehingga data yang dihasilkan lebih efektif, maksimal, dan lebih akurat. Metode pengembangan sistem yang digunakan adalah RAD (Rapid Application Development) dengan pemodelan UML (Unified Modeling Language) dan menggunakan Kotlin sebagai bahasa pemrograman Android Studio. Hasil dari aplikasi ini dapat memudahkan konsumen dalam mengetahui informasi produk dan stok produk sehingga konsumen tidak perlu datang ke rumah cantik G\&G. Setelah dilakukan pengujian di dapat hasil pengujian yang dilakukan oleh Ahli Media dengan persentase $100 \%$, Kuesioner Responden Pemilik dengan persentase $80 \%$ dan Kuesioner Responden pelanggan dengan persentase $78,25 \%$, dapat disimpulkan bahwa Aplikasi Rumah Canti G\&G sangat layak untuk digunakan. Aplikasi ini juga dilengkapi pemberitahuan pesanan sehingga konsumen dapat lebih mudah mengetahui informasi produk yang dipesan di rumah cantik G\&G. 


\section{Keywords: Abstract:}

$G \& G$ Beautiful House Application, RAD, Kotlin, Android Studio
$\mathrm{Nu}$ Skin is one of the beauty and health products, one of which is located in Jepara, namely the G\&G Beauty House which has an office on Jl. Diponegoro No. 121, Jobokuto, Jepara District. Marketing of the product is still only manual through the media (Instragram and Whatsapp), every time the product is purchased, consumers must come to the store to find out the available product inventory. Judging from these problems, it is necessary to have an android-based application that can help sales activities ranging from promoting products, knowing product information and product stock so that the resulting data is more effective, maximum, and more accurate. The system development method used is RAD (Rapid Application Development) with UML (Unified Modeling Language) modeling and using Kotlin as a programming language with Android Studio. The results of this application can facilitate consumers in knowing product information and product stock so that consumers do not need to come to the $G \& G$ Beauty House. Based on tests conducted by Media Experts with a percentage of 100\%, Owner Respondents Questionnaire with $80 \%$ percentage and community / customer Respondents Questionnaire with a percentage of $78.25 \%$, it can be concluded that the $G \& G$ Beautiful Home Application is very feasible to use. This application also features order notifications so that consumers can more easily find out product information ordered at the $G \& G$ Beauty House. 


\section{PENDAHULUAN}

$\mathrm{Nu}$ Skin merupakan sebuah produk kecantikan dan kesehatan yang berdiri sejak tahun 1984 dan berpusat di Utah, USA. Tingginya minat masyarakat Indonesia untuk tampil lebih muda membuat $\mathrm{Nu}$ Skin mulai masuk dan menawarkan solusi kecantikan, manfaat yang diberikan oleh $\mathrm{Nu}$ Skin tidak hanya menjadikan konsumen sebagai pelanggan tetap dengan menggunakan produknya saja, akan tetapi pelanggan juga bisa menjalankan hak bisnisnya sebagai distributor yaitu dengan menjual produknya kembali.

Pemasaran produk Nu Skin yang salah satu berada di Jepara yaitu pada Rumah Cantik G\&G yang mempunyai kantor di Jl. Diponegoro No. 121, Jobokuto, Kecamatan Jepara. Produk yang ditawarkan memiliki banyak manfaat bagi kesehatan kulit dan kesehatan tubuh. Pemasaran produk Rumah Cantik G\&G hanya memasarakan produknya melalui media (Instagram dan Whatsapp), akan tetapi setiap pembelian produk konsumen harus datang ke toko untuk mengetahui persediaan produk yang ada.

Dengan memanfaatkan kemajuan teknologi smartphone merupakan salah satu solusi.Oleh karena itu dibutuhkan sebuah aplikasi berbasis mobile yang dapat memberikan informasi mengenai penjualan dan pemesanan produk pada Rumah Cantik G\&G. Diharapkan dengan menggunakan aplikasi ini nantinya para konsumen mendapatkan informasi yang dibutuhkan dengan cepat. Aplikasi ini nantinya dikembangkan dengan sistem operasi Android, yang mana perkembangan android sudah semakin canggih, sehingga banyak yang dapat menggunakan aplikasi ini pada smartphone berbasis Android.

Untuk mengatasi permasalahan pada Rumah Cantik G\&G, peneliti membuat suatu aplikasi yang dapat membantu kegiatan dalam penjualan mulai dari mempromosikan produk, mengetahui produk dan stok produk.Agar data yang dihasilkan lebih efektif, maksimal, dan lebih akurat.

Aplikasi ini dikembangkan menggunakan metode RAD (Rapid Aplication Development) sebagai metode pengembang sistem, metode ini dipilih guna untuk mempersingkat waktu pengembang, selain itu perancangan dan implementasi pada model ini disesuaikan dengan pengguna sehingga menghasilkan sistem sesuai dengan kebutuhan pengguna.Dengan adanya aplikasi ini diharapkan dapat memberi informasi bagi pelanggan tentang berbagai macam produk dan stok produk yang ada pada Rumah Cantik G\&G. 


\section{METODE}

Dalam penelitian ini metode yang digunakan peneliti adalah metode Rapid Appliation Development yang sudah terstruktur dalam penerapan sistemnya yang meliputi (Requirements Planning (Perencanaan Syarat-Syarat), RAD Design Workshop (Workshop Desain RAD), Implementation (Implementasi)) seperti pada gambar di bawah ini:

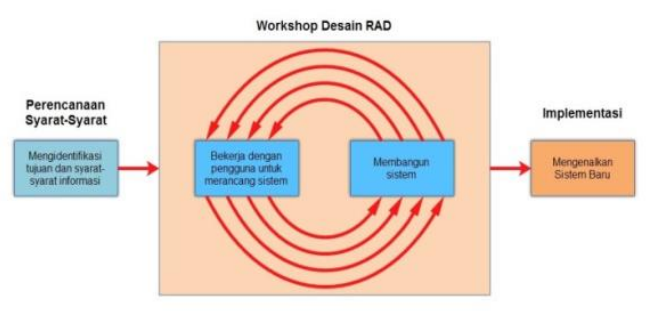

Gambar 1 Metode RAD

\section{HASIL}

Kelayakan aplikasi Rumah Cantik G\&G telah diuji dan dinilai oleh ahli media serta dilakukan penyebaran angket kepada 40 responden dengan hasil sebagai berikut :

Tabel 1 Tabel Hasil Pengujian

\begin{tabular}{ccccc}
\hline No & Penguji & $\begin{array}{l}\text { Nama } \\
\text { Penguji }\end{array}$ & Nilai & Kriteria \\
\hline 1. & Ahli Media & Nur Aeni & 100 & Sangat \\
& & Widiastuti, & $\%$ & Layak \\
& & S.Pd., & & \\
& & M.Kom & & \\
2. & Pemilik & Dwi & $80 \%$ & Sangat \\
& Rumah & Santhika & & Layak \\
& Cantik G\& & Sari & & \\
3. & Masyarakat & 40 & 78,2 & Sangat \\
& /Pelanggan & Responden & $5 \%$ & Layak \\
\hline \multicolumn{6}{c}{ Berdasarkan tabel hasil pengujian }
\end{tabular}

dapat disimpulkan bahwa untuk ahli media mencapai $100 \%$ dan berkriteria sangat baik, responden pemilik usaha $80 \%$ dan responden masyarakat/pelanggan 78,25\% yang menghasilkan kesimpulan sangat layak sehingga aplikasi dapat digunakan oleh toko untuk proses penjualan produk.

\section{PEMBAHASAN}

\section{Perancangan Aplikasi}

Perancangan aplikasi mobile ini diberi nama Rumah Cantik $G \& G$ dengan menggunakan metode RAD (Rapid Application Development) dengan tahapan Requirement Planning, User Desain, Build Sistem dan Implementation. Pelaksanaan keseluruhan prosedur pengembang penelitian ini secara rinci dapat dilihat sebagai berikut:

\section{Requirement Planning (Perencanaan}

\section{Kebutuhan)}

Aplikasi ini diperuntukkan untuk pengguna umum atau kalangan muda mudi maupun lanjut usia khususnya pecinta skincare yang kurang paham akan adanya Rumah Cantik G\&G dan pemasaran secara Online yang ada di kabupaten Jepara. Dengan adanya informasi ini akan mempermudah masyarakat dalam mencari informasi produk dan stok produk.

\section{User Desain}

1. Deskripsi Sistem 
Untuk dapat menjalankan aplikasi secara lebih mudah dan sederhana.untuk pemesanan produk Nu Skin pada Rumah Cantik G\&G seperti gambar berikut:

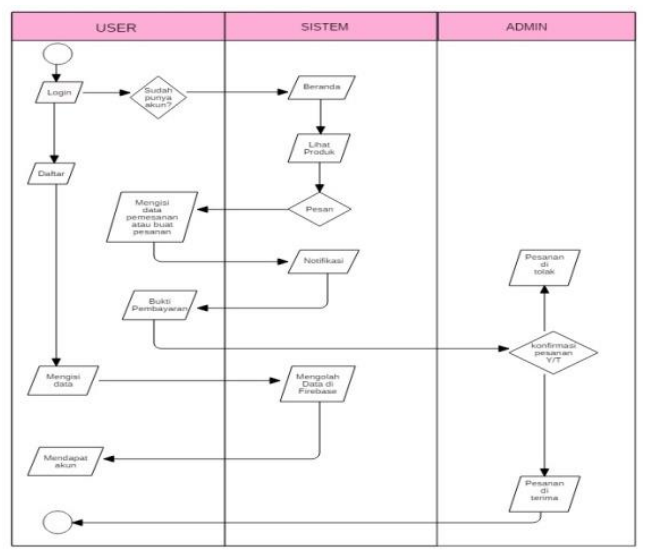

Gambar 2. Flowchart Diagram

\section{Use Case Diagram}

Use case diagrammendefinisikan fiturfitur yang terdapat dalam Aplikasi Rumah Cantik G\&G. Use case diagramdapat dilihat pada gambar berikut :

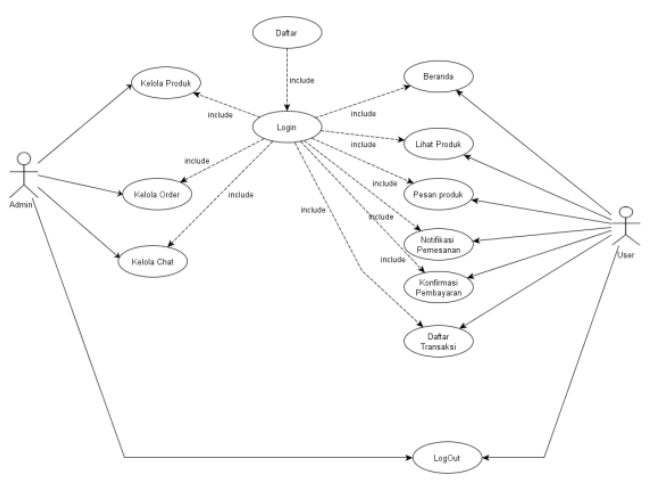

Gambar 3. Use Case Diagram

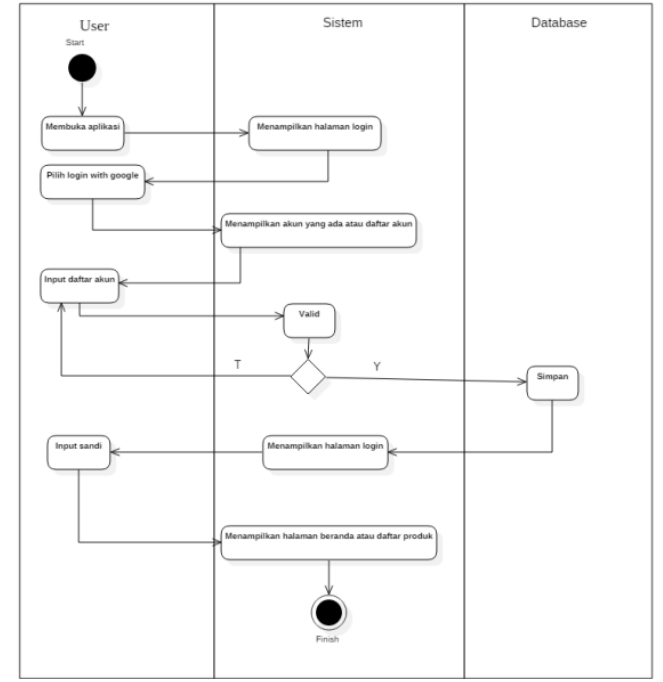

Gambar 4. Activity Diagram Login User

User membuka aplikasi dan sistem menampikan halaman login kemudian user klik button login with google lalu sistem akan menampilkan akun yang terkait atau daftar akun kemudian user menginput daftar akun dan sistem akan memvalidasi data user jika data sudah benar maka akan disimpan namun jika data salah maka sistem akan kembali ke input daftar akun. Selanjutnya sistem akan menampilkan halaman login kembali dan user menginput sandi setelah sukses login sistem akan menampilkan daftar beranda atau daftar produk.

3. Activity Diagram
a. Aplikasi User
1. Activity Diagram Login User 
4. Activity Diagram Pemesanan User

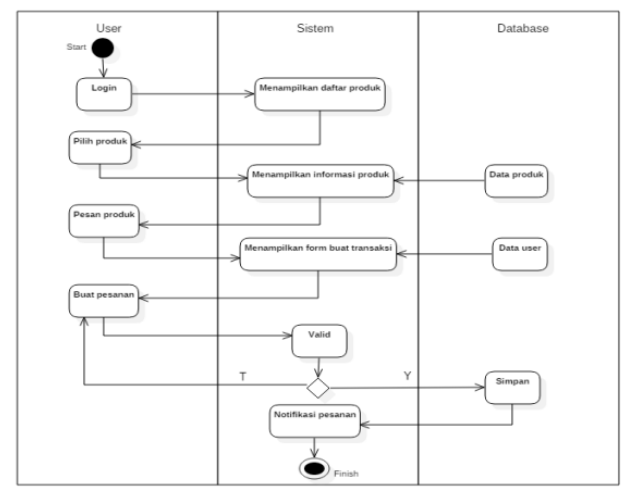

Gambar 5. Activity Diagram Pemesanan

User melakukan login dan sistem akan menampilkan daftar produk, lalu user memilih produk dan sistem menampilkan data informasi produk yang diambil dari database. Kemudian user melakukan pesan produk lalu sistem menampilkan form buat transaksi data user yang diambil dari database, kemudian user buat pesanan jika sistem valid maka database akan menyimpan, kemudian sistem menampilkan notifikasi pesanan.

5. Activity Digram Pembayaran Transfer Bank User

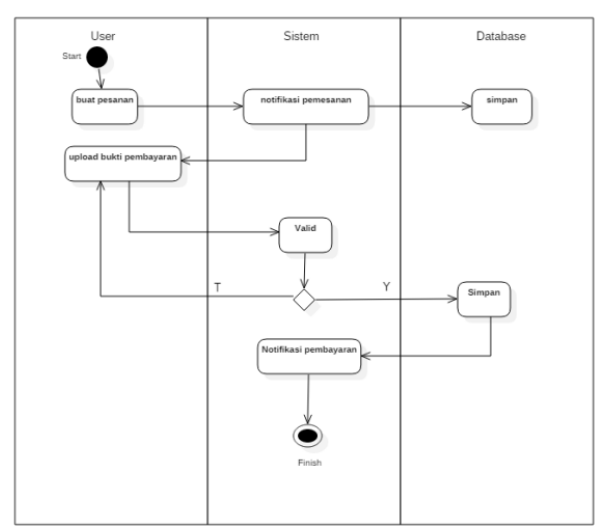

Gambar 6. Activity Diagram Pembayaran Transfer Bank User
User melakukan buat pesanan dan sistem akan menampilkan notifikasi pesanan lalu database menyimpan. Kemudian user upload bukti pembayaran dan jika valid maka database akan menyimpan, lalu sistem menampilkan notifikasi pembayaran.

\section{Activity Diagram Login Admin}

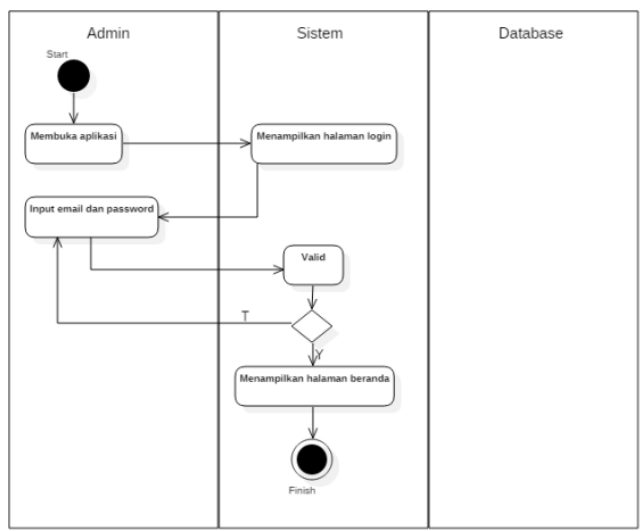

Gambar 7. Activity Diagram Login Admin

Admin membuka aplikasi dan sistem menampilkan halaman login. Kemudian admin memasukkan email dan password untuk masuk admin toko.

7. Activity Diagram Konfirmasi Order

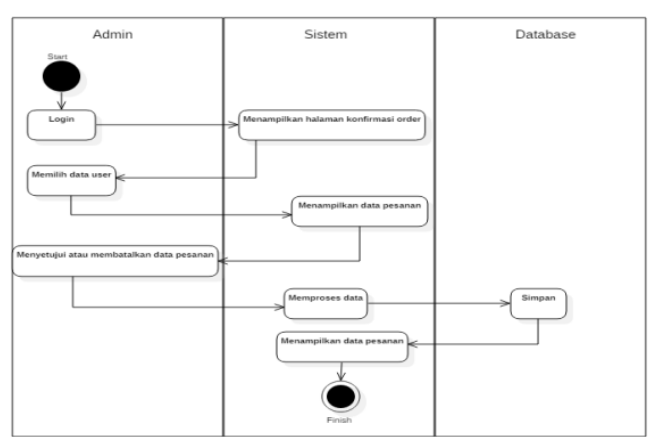

Gambar 8. Activity Diagram Konfirmasi Order 
Pertama admin melakukan login, setelah itu sistem akan menampilkan halaman konfirmasi order. Kemudian admin memilih data user dan sistem akan menampilkan data pesanan. Lalu admin mengkorfirmasi atau membatalkan data pesanan, setelah itu sistem akan memproses menyimpan data dan menampilkan data pesanan.

\section{Class Diagram}
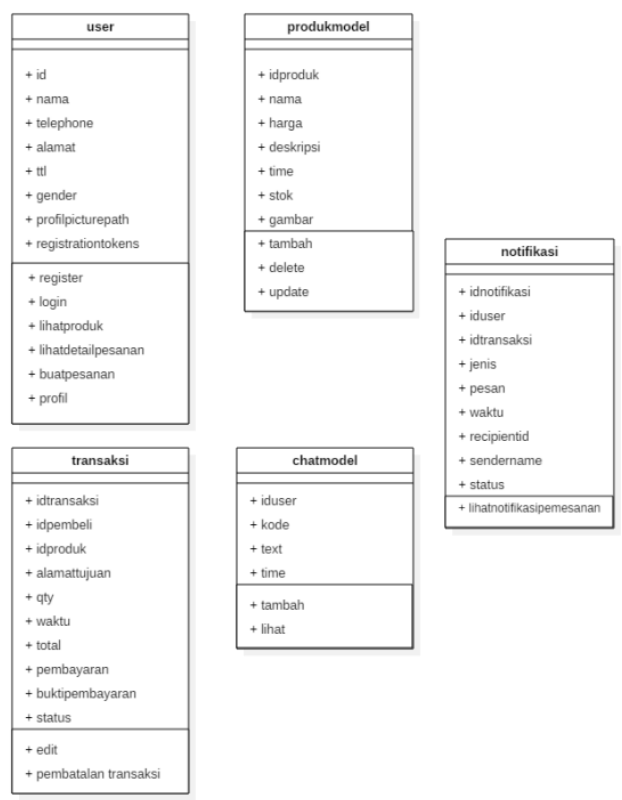

Gambar 9. Class Diagram

\section{Implementasi}

Berikut ini merupakan implementasi aplikasi ketika dijalankan di device android secara langsung Device yang digunakan yaitu Realme C2.

\section{Tampilan Menu Login}

Halaman login merupakan halaman yang muncul pertama kali ketika aplikasi di jalankan.tampilan dari halaman login user dapat melakukan login with google lalu jika belum pernah login maka user bisa memasukkan email, nama, dan password gambar dapat dilihat sebagai berikut :

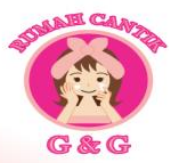

G I Login with Google

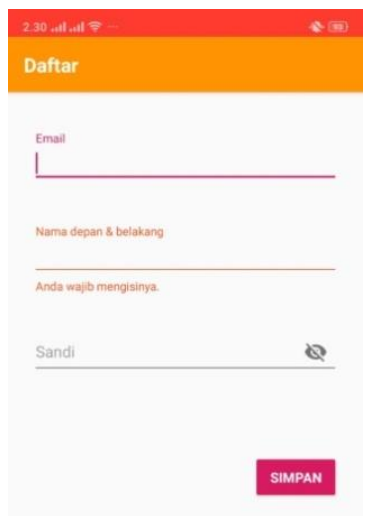

Gambar 10. Tampilan menu login

\section{Tampilan Menu Beranda}

Perancangan Menu Beranda ini merupakan menu yang pertama kali muncul setelah Pengguna Login.Halaman Beranda ini terdiri dari daftar produk. Rancangan tampilanya sebagai berikut: 


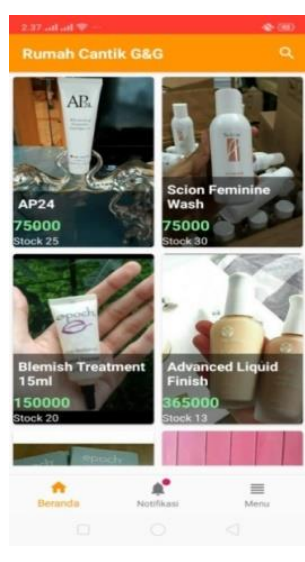

Gambar 11. Tampilan menu login

\section{Tampilan Detail Informasi Pesanan}

Pada tampilan ini, jika user ingin membeli produk maka bisa melakukan pesan sekarang. Tampilan bisa dilihat seperti gambar dibawah:

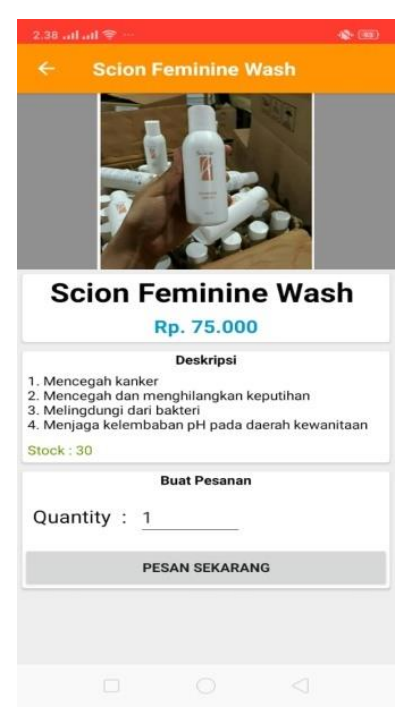

Gambar 12. Tampilan menu login

\section{SIMPULAN DAN SARAN}

Aplikasi Rumah Cantik G\&G dapat mempermudah pemilik toko dalam membuat laporan hasil penjualan dari toko dan mengetahui daftar dari semua pelanggan yang sering membeli ditoko.
Aplikasi Rumah Cantik G\&G dapat menghindari kesalahan pelayanan yang sering terjadi saat membeli langsung ketoko tanpa mengetahui stok dan ketersediaan produk yang diinginkan sehingga membuat konsumen merasa kecewa. Aplikasi Rumah Cantik G\&G sudah dapat memudahkan konsumen pada saat akan mengetahui produk dan stok produk sehingga memudahkan konsumen dan tidak perlu datang ke toko lagi.

Peneliti menyadari bahwa dalam penelitian ini masih jauh dalam kesempurnaan, maka pada kempatan ini peneliti ingin memberi saran demi menyempurnakan penelitian yaitu Aplikasi Rumah Cantik G\&G dapat dikembangkan lebih lanjut dengan menambahkan fitur diskon. Dalam pengembangan aplikasi selanjutnya, pembayaran bisa dilakukan dengan cara online atau dengan uang elektronik seperti Go-pay, E-money, Cash, OVO. Dalam aplikasi selanjutnya, pada fitur perhitungan ongkos kirim dapat dilakukan berdasarkan jarak $(\mathrm{km})$ karena perhitungan masih dalam kota. 


\section{DAFTAR PUSTAKA}

L. D. R. D. Rinda Ayu Rismanita, Edriana Pangestuti, "Pengaruh Perceived Value Dan Satistfaction Terhadap Brand Loyalty (Survei pada Pelanggan Produk Nu Skin di Distributor Resmi Perumahan Aluminium Kota Malang)," J. Adm. Bisnis, vol. 63, no. 1, 2018.

A. Irawan, M. Risa, M. A. M, and A. E. S, "Perancangan Sistem Informasi Penjualan Pakaian Pada Cv Nonninth Inc Berbasis Online," J. Positif, vol. 3, no. 2, pp. 74-82, 2017.

A. P. Kusuma and K. A. Prasetya, "Perancangan Dan Implementasi ECommerce Untuk Penjualan Baju Online Berbasis Android," ANTIVIRUS J. Ilm. Tek. Inform., vol. 11, no. 1, pp. 1-11, 2017.

M. w. M. Resdea Restin Yulia Roza, Nur Nafiyah, "Sistem Penjualan Online Pada Dea Kosmetik Lamongan," $J$ TIIES, vol. 1, no. 1, 2017.

G. Tesaria and S. Mardira Indonesia, "Aplikasi Penjualan Online Berbasis Android (Studi Kasus: Di Toko Hoax Merch ), J J. Comput. Bisnis, vol. 10, no. 1, pp. 40-49, 2016.

I. M. A. P. Putu Agus Darma Santosa, Gede Saindra Santyadiputra, "PYLE : Aplikasi E-Commerce Berbasis Web Menggunakan Sistem Informasi Geografis," Kumpul. Artik. Mhs. Pendidik. Tek. Inform. (KAR M APATI), vol. 6, no. 1, 2017.

O. J. I. I'in Endang Mardiani, "Analisis
Keputusan Pembelian Konsumen Melalui Media Online (E-Marketing), $J$. Ekon., vol. 4, no. 2, 2013.

Riyono and E. B. Gigih, "Pengaruh Kualitas Produk, Harga, Promosi dan Brand Image terhadap Keputusan Pembelian Produk Aqua di Kota Pati," J. STIE Semarang, vol. 8, no. 2, pp. 92-121, 2016.

Juansyah Andi, "Pembangunan Aplikasi Child Tracker Berbasis Assited - Global Positioning System ( A-GPS ) Dengan Platform Android Jurnal Ilmiah Komputer dan Informatika ( KOMPUTA )," J. Ilm. Komput. dan Inform., vol. 1, no. 1, pp. 1-8, 2015.

L. A. Sandy, R. J. Akbar, and R. R. Hariadi, "Rancang Bangun Aplikasi Chat pada Platform Android dengan Media Input Berupa Canvas dan Shareable Canvas untuk Bekerja dalam Satu Canvas Secara Online," J. Tek. ITS, vol. 6, no. 2, 2017.

N. R. dan R. Toro, Kotlin Android Developer Expert. Bndung: PT. Presentologics, 2018.

M. S. Mustaqbal, R. F. Firdaus, and H. Rahmadi, "( Studi Kasus: Aplikasi Prediksi Kelulusan SNMPTN )," Penguji. Apl. Menggunakan Black Box Test. Bound. Value Anal. (Studi Kasus Apl. Prediksi Kelulusan SNMPTN), vol. I, no. 3, p. 34, 2015.

I. G. Tofik Isa and G. P. Hartawan, "Perancangan Aplikasi Koperasi Simpan Pinjam Berbasis Web," Ilm. Ekon. Vol. 5 Ed. 10, vol. 5, pp. 139-151, 2017. 
S. Kosasi and I. D. A. E. Yuliani, "Penerapan Rapid Application Development Pada Sistem Penjualan Sepeda Online," Simetris J. Tek. Mesin, Elektro dan Ilmu Komput., vol. 6, no. 1, pp. 27-36, 2015.

R. Hadapiningradja Kusumodestoni, Adi Sucipto, "Android-Based Game Puzzle Development as a Media for Introduction of Tourist Objects in Jepara Regency”, 1st International Conference on Education and Social Science Research (ICESRE 2018), 2019

G. Urva, H. F. Siregar, J. Prof, M. Y. Kisaran, and S. Utara, "Pemodelan UML EMarketing Minyak Goreng," J. Teknol. dan Sist. Inf., vol. 1, no. 9, pp. 92-101, 2015. 